\title{
Fulfilling a Failed Dream: School Dropout and Second Chance Schools
}

\author{
Elena Papachristopoulou, Pandelis Kiprianos, Michael Christodoulou \\ Patras University \\ Email: kiprian@upatras.gr
}

\begin{abstract}
This article aims to investigate school dropout before the completion of compulsory education. The material consisted of the life stories of 26 adult learners at the Second Chance Schools (SCS), which were analysed using the biographical method. Interviews were also held with 4 teachers at the SCS. The questions were organised around five axes: childhood pathways, reasons for dropping out of school, consequences of this decision in their life, reasons for re-entering education and additional biographical designs. Four thematic fields emerged, based on which school dropout is articulated narratively and given meaning as a life choice: a) early involvement with the job market or the creation of a family, b) family life as a "problematic situation", c) emigration and d) learning difficulties.
\end{abstract}

Keywords: Second chance schools, school dropout, biographical method, life stories, school investment.

\section{Introduction: Research Object}

Research regarding the performance of the students who drop out of compulsory education prematurely shows that these students face learning difficulties long before tangible signs of abandonment appear (Bonnery, 2003). The origins of school dropout can be found in childhood experiences in the family or in the public school (Lessard, Butler-Kisber, Fortin, 2007; Fortin, 2012). Repeating a school year, difficulties with reading and writing constitute evidence of possible future dropout (Douat, 2012). Distancing oneself from the learning process, withdrawal, behaviours leading to interruption or marginalization which are observed with the entry of the student into secondary education (Hugon, 2010) are already apparent from the primary school.

School factors prove significant but they are not the only ones. They are influenced by other factors, family, social or personal. This ascertainment seems to go beyond national borders. All societies face the same problem, which expresses itself in different ways. Educational policy, the structure of the school systems and their values influence, either directly or indirectly, school abandonment. School dropout is highlighted hence as a multi-factorial process, dating back to the very early age. Focussing our research on dropout, Bernard claims, covers up the deeper-rooted causes of the phenomenon, which is registered on the individual trajectories and the social and school framework of reference (Bernard, 2011). In the dominant discussion regarding school failure, dropout constitutes a symptom of the family and social environment, the means for perceiving school failure in all its magnitude, with all the connotations of the term "dropout" and the "deep interweaving of the school with the social" (Glasman \& Oeuvrard, 2011).

In the present text we attempt to investigate two questions through the life stories of the students of an institution in Greece which addresses adults who had left school early, the Second Chance Schools (SCS). Firstly, the reasons for which in the past they left school prematurely and their current attempt to reintegrate themselves and complete compulsory education. Secondly, the contribution of the SCS to the learners' identities, in other words the extent to which knowledge, skills, and the degree certificate have consequences for the shaping of their identity.

The above are shaped into the following research questions:

1) What were the reasons for abandoning school and how is this event engraved on their biographical identity and the way they organise their signifying axes? 
2) What led them to the decision to re-enter education and more specifically in the Second Chance Schools?

3) What aspects of their personal and social identity were affected by their integration into the SCS and how have the learners themselves experienced it?

\section{The Concept of Identity}

The life accounts organise the wealth of the individual's experience through the meanings he assigns to central events in his past. The individual combines his life transitions and the crucial biographical moments that have been part of his life in a narrative whole. When people talk about their lives, they articulate narratives about the forms of life they consider "superior" and "inferior" in relation to which they themselves are integrated, want to be integrated, or not. As the individual narrates his life he becomes involved in a discursive confrontation with those forms of life in which there are things which count and distances himself from those forms of life in which there aren't things that count. The articulation of the experiences which is reflected as the individual speaks about himself and everything he has experienced, organises those experiences not chronologically or causally but narratively (Dubar, 1999; Demaziere \& Dubar, 1997).

The identity that is produced through the narrating of the self is the meeting point of the individual and collective history in the following senses: a) the individual doesn't create from scratch the what and how of the narrative since he draws on narrative patterns and techniques either from the wider society in which he lives (the Grand Narratives) or from the culture of his origin, b) he is obliged to handle and deal as much with the consequences in his everyday life which are a result of macro-structural developments (changes in the labour market or welfare state policies) as the micro-developments which are linked to his family or his profession. Hence, the social is not isolated from the individual, rather they are interwoven, since it is the bearer's produced narrative that binds him to the historical life-world of which he constitutes a part. Therefore, different cultural Discourses "speak" (in other words, are heard) in the individuals' life stories and, hence, the biographies of the individuals are mediated by society. This can be seen when someone speaks about his life as a narrator not only of his biographical impressions but as a member of a generation, a cohort, a social class and so on (Bertaux, 1980)

\section{Methodology}

\subsection{Research Technique}

From the aforementioned, it follows that the biographical method is the more effective means for the examination of the processes surrounding the development of the self. More specifically, the method in question focuses a) on the reconstruction of the development of the whole of the individual's identity throughout his life. This synchronic presentation of the self is analysed in relation to the life as lived and the life as told. The aim of this emphasis is the promotion of everything that is not mentioned in the interview but which exists below the surface of the presentation of the self and how the individual attempts to impart cohesion between what he was and what he has become and b) on the semantics that are used for someone to perform biographical actions and to position himself. The aim is the understanding of the orientations of the individual's action as against conditions of negative experience which cause the disruption of the self and biographical ruptures.

\subsection{The Research Sample}

Given that the aim of the research was the investigation of the relationship between the development of biographical identity and a critical biographical event (in other words, school dropout), we chose homogenous sampling as the most appropriate. Since the SCS accepts individuals who abandoned school early, it follows that we are concerned with the study of a group whose members share the biographical event in question. In addition, through this sampling strategy we were able to locate not only the different narrative reconstructions which are related to this event but also the different cycles (work, family, learning) which the members of this group followed (Patton, 1990:169), (Creswell, 2011). In 
other words, despite being homogenous in terms of the experience of school dropout, the SCS students present differing confrontational experiences with marginalization, in the sense that, although all were of working class origin, the life transitions of the older ones were more predictable and secure due to the nature of the traditional jobs of the working class, in contrast with the younger ones, whose life transitions are typical of that which has been called "precarious" (Ross, 2013), (Standing, 2011). Based on this data, we divided the interviewees into two groups, the first with young people aged 18-40 and the second with those aged 41 and above based on work and future plans: the young aim at continuing their education and professional development, while the older ones are already "sorted" socially and professionally and aspire to the completion of secondary school education as a life dream. The interviews were held during the 2014-2015 school year at the SCS in the city of Patras in Western Greece. The final sample was made up of 26 students, 10 men and 16 women, a proportion which reflects their distribution by gender.

\subsection{Conduct and Analysis of the Interview}

The interviewees were invited to narrate the story of their life, to relive their personal experience. The narrative interview was designed based on five axes: childhood, school experiences, life after school work experiences, daily life at the SCS, as well as reflective questions. The interviews of the 26 learners took place between March and June, 2015. In addition, we interviewed 4 educators and these interviews functioned as, validating findings, triangulation, as well as an approach to the research questions from different points of view, investigating "the mental puzzles globally and from all sides" (Mason, 2002).

The interviews were conducted in three phases: in the first phase of the main narrative the learner was invited to narrate the story of his life around the five axes, in the second phase, of the ancillary questions, the researchers asked for clarification of any vagueness or gaps in the free narrative and in the third phase, of the free questions and the accounting, the narrator was called on to assess his life and/or talk about his plans for the future.

The interviews were recorded and, then, transcribed in accordance with Silverman's techniques (2000: 298-299). They were then analysed based on the principles of narrative analysis (Schutze, 1983: Demaziere, 2003), (Riessman, 2008), (Wengraf, 2000), (Spector-Mersel, 2011) and chiefly the reconstructive biographical method was used and Rosenthal's methodological principles (2004/2013:8183) which recommend the overall, framed and deductive analysis of the narratives.

As is evident in Fig. 1, and following Schutze (1983), we organised the data-base with the transcriptions of the narrative interviews and we enriched it with notes and observations from the research field. We then drafted a chronology for each learner, and advanced to textual analysis focusing on structural and morphological features. Next, we focused on the structural description, reconstructing the past viewpoint of the teller of the biography and the significance that each event took on in the experienced time, relating it to his present viewpoint, as well as the significance it acquires in the structuring and presentation of the biography. In the analytical induction, we moved from the details to the whole, from the particular to the general. In this way, we highlighted seven patterns, from which, due to overlapping as well as the reprocessing of their chief characteristics, we arrived at the four which are explained in the following chapter.

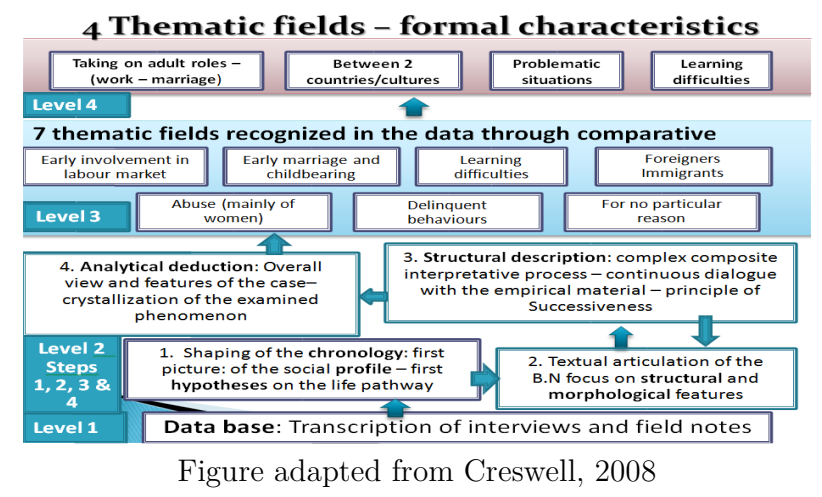

Figure 1. Levels in the qualitative study of SCS learners 


\subsection{1 $1^{\text {st }}$ Thematic Field: Early Involvement in the Job Market and the Starting of a Family at a Very Early Age}

In this pattern the dominant factor in dropout - more usual in the case of the men - was work. The choice appears to be personal, but it is linked to difficult economic conditions. Take the case of 29 yearold A.

1. He was born and grew up in a village, and completed the second year of secondary education (year 8). He left school to work in the family livestock business when his older brother was called up to do his military service and A had to take his place.

2. When his brother returned 2 years later, he didn't return to school because his friends and peers had already graduated from Junior High School.

3. Since then he has been working in the family business and for 2-3 years he worked in a car workshop, from which he was fired.

4. He learned about the SCS and registered in 2013. He wanted to go on to the Technical High School and specialise as a car mechanic.

From the course of his life, it is clear that A left school because his father, who gave priority to the family business, obliged him to - in contrast with his mother.

E-I want you to narrate your experiences from your childhood until today in relation to school - why you left, when you left and why you find yourself here today.

"Fine, I stopped school, in Year 8 in the middle of the school year because my brother left for his military service and we had a lot of work, I mean there was some machinery that I knew how to use and that's why I left,...my father couldn't work the machinery since he's illiterate and he doesn't know anything about computers and stuff so I took over..."

"My father didn't mind about me not going, you see...just my mum pressured me, go and go and go to school but I didn't go..."

A didn't return to school. He presents the decision as his own, because his group of friends had left school and he was afraid of being stigmatised because of his age.

"... me...eee..my brother was away for 18 months and once he finished I mean he finished with the army I didn't want to go back to school because my friends had left, that was the reason and I put it off and put it off and put it off..."

Despite his limited work experience, A seems to be aware of the job opportunities he has missed due to not having graduated from high school. He understood the value of certification and registered in the SCS, determined to continue on to the Technical High School.

"...after this I will probably continue on to the Technical High School for car mechanics because I have a little workshop in the village and I work there too and I'll try you know to get the certificate so it'll be legal..."

\subsection{2 $2^{\text {nd }}$ Thematic Field: Intensely Problematic Situations}

This pattern includes women who were, as minors, victims of abuse either within the family or outside of it. Here we also included those who had been in trouble with the law, had a history of abuse or faced serious family problems. Serious dysfunction within the families, which had an impact on the individuals, emerges from their narratives.

40 year-old E, the child of a poor, large family, mentions the frequent beatings her mother and siblings suffered at the hands of her father. He forbade them from going to secondary school, in order to work and he kept all the money himself. The chronology of her life path is as follows:

1. She was born in Patras and completed primary school. She stopped going to school when she was 12-13, although she did try to go to high school in secret for 3 months, with the support of her mother, since her father demanded that she work with him

2. At 15 she started to work in factories and later as a delivery woman, with all her earnings going to her father.

3. At 30 she met $G$. and they planned to marry but his death in a road accident destroyed everything. E. had a nervous breakdown and had serious psychological problems.

4. At 35, after a long period of suffering and disruption, she began to feel better, learnt about the SCS, registered (2013), in the hope of continuing on to senior high school.

E.'s reasons for dropping out are obvious: the refusal of her uneducated father, who demanded that after high school all his children follow him in his job (extraneous factor), as well as her own decision- 
weakness to follow lessons and read at school when her daily life was full of tension and shouting (extraneous factor).

-E: Didn't she (the mother) help you enough?

"She helped as much as she could, yes. And she talked to us about that so that at some point they will stop school my father said and they'll come out to sea with me...all the children as soon as they finish the last year of primary school. I only went to secondary school for three months, in secret from my father so he wouldn't find out", -E: was he (the father) completely against it?

"Yes, regarding school, yes. Because he hadn't finished his schooling...I didn't have the strength to attend school then I tell you and that it seemed to me very difficult to open a book with the tension and shouting I preferred to be out of the house the children were outside in the vacant lot, just to get out of the house to pretend that nothing was going on"

The father wasn't satisfied with the refusal and continued to abuse.

"... difficult things and in the family the parents fighting my father was running about with women (...) he didn't care about his family and children and however we tried this had an effect on us as children, to see our parents fighting and for there to be no understanding in the house about what was said in front of the children for there not to be fights as the oldest then, all this has stayed with me"

-E: can you remember events, something that bothered you a lot something that has stigmatised you (within the family)?

"Yes, that he hit my mother a lot and that the blood hit the walls is a picture that will never leave my eyes or my mind and I try not to go back there"

E: Did he beat you too?

"Yes, all the children..."

E.'s tough experiences of work and without her being able to enjoy the fruits of her labour, drove her to realise the value of the high school leaving certificate.

E: So tell me something that had bothered you from the stigma as you say of the primary school or when they didn't take you on to work or something that someone said to you

"Yes with the job bulletins that come out that you have to be there the limit for primary school is 1980, I finished in 1985 and even then you need to have finished high school to get in so us, the generation of those 5 years isn't that stigma?"

Reintegration into education for E. is a long held desire, as well as a conscious decision due to the difficulties she encountered in finding work. Hence she is enjoying her experience at the SCS and is thinking of continuing further.

-E: Here, about this school, how did you hear about it?

"From acquaintances...my first thought was to come along and get my leaving certificate but as time passed I saw that it wasn't just the leaving certificate, I've got a lot out of it, I mean the knowledge you gain from the people, the professors, the lessons, the way you have to study the way I mean, it's not just the leaving certificate in the end it's the lessons because when I came here I said to myself I'm not interested in the lessons, ok, whatever I learn.

I want the leaving certificate. It's not like that though. You change as time passes. When someone really wants to learn and it's something that's been repressed inside him like it was for me then you get something out of it, you learn"

\subsection{3 $3^{\text {rd }}$ Thematic Field: Living in Two Countries, the Fate of the Immigrant}

Learners who spent their school years in two countries are placed in this pattern. Regardless of their nationality, in the interviews they displayed many common characteristics, such as a traumatic event (divorce, war...) that forced them to emigrate with their families. The constant coming and going between two countries made their presence in school impossible. So, when they could attend school, they had lost valuable time or they could no longer keep up due to the 'gaps' in their learning, lack of familiarity or certification from the educational system of the country they lived in.

32 year-old K., the youngest child from a large family of economic migrants in Greece, narrates her life path.

1. She was born in Albania, her parents emigrated to Greece, she grew up with her grandmother and completed primary school (12-13 years old) in her native country. 
2. She doesn't register for secondary school in either Albania or Greece because she was coming and going for roughly two years between the two countries. At the same time she doesn't have her parents' support since they give priority to making a living.

3. Once she moves to Greece permanently she begins to work immediately in order to survive, as well as to feel that she is independent of her parents.

4. She got married at 20 and had a son straight away. Due to a long period of unemployment and in agreement with her husband, who is a high school graduate, she enters the SCS.

Referring to the interruption of her studies, K. is very clear.

-Until the age of 15 when you came to Greece, didn't you go to school - high school - for

those two years?

“...no no no I didn't go to school for those two years because I was always coming and going"

-E: Didn't you want to go or...?

"I didn't want to go, no, I didn't want to go. It's that when you are young you don't think logically and I say that I made a mistake when I came here and I didn't go to school"

When she moved permanently to Greece with her parents, K. looked for work, "to earn a living". She stresses the lack of parental guidance, as well as her "naïve" decision not to continue with school.

"The primary school but I didn't have help I didn't have my mum nearby and then I came here and got a job my mum came firstly I was young and I didn't think logically I mean I liked getting the money because I'm someone who doesn't want to ask I want to have my own money",

K. avoids talking about her experiences of work. She stresses the difficulties she encountered in the jobs she did, her inadequate knowledge of greek and the consequences that had for her professional development.

-E; What kind of jobs did you do?

"I work in the kitchen... yes yes in restaurants,...hard work. I have worked, the hardest work

I have done here in Greece was when I was small, with the olive harvest...very hard work, E! and in the kitchen",

"I have encountered difficulty in my life I mean in the shop where I worked if you don't know how to read well you can't take an order...e... I have had difficulties and I wanted..."

K. appears to be conscious of her relationship with school. She graduated from primary school in Albania, but her attendance coincided with two negative events for her: her parents' emigration to Greece and political tension in the country of her birth. The absence of her parents (she lived with her grandmother) and the poor functioning of the school she was attending affected her greatly.

"When I was in primary school it was when the war had started it was a mess there they

left us and they didn't do lessons with us they locked us in the school you know and just sit there until the time passes my time wasn't a good time"

She has a realistic approach to her reintegration into school through the SCS, stating that her primary goal is to learn to speak and mainly to write greek.

\subsection{4 $4^{\text {th }}$ Thematic Field: Learning Difficulties as Reason for School Dropout}

Learners who cited diagnosed learning difficulties which obstructed them from continuing with school were placed in this pattern. They describe the disorder, its symptoms, as well as the weakness or refusal of the greek education system to recognise the problem and allow them to complete their education. We also integrated individuals who didn't determine exactly the reason they abandoned school, but who talk about boredom in the classroom and demonstrate hyperactivity, into this pattern: the narratives of the latter fit the symptoms of hyperactivity and attention deficit. These individuals abandoned school more than once, trying from time to time to reintegrate and graduate from high school.

Let's take a look at the example of 47 year-old D., a cleaner with a permanent position in a public service.

1. She was born and grew up in Patras, where she completed her primary schooling.

2. She continues on to high school, but has to redo the first two years, a difficulty which leads, in conjunction with a serious health problem concerning her father, her to abandon school.

3. She works in the family business and at the same time on short term contracts in the public sector where she is eventually made permanent. She married, but separated after 13 years without children. 
4. She enters the SCS and wants to continue on to senior high school her objective being better career progression within the public sector.

Referring to the reasons she abandoned high school, D. puts forward her father's illness when she was 13-14 and the need for her to work in the family business. However she also mentions the difficulties she had with the lessons, chiefly maths and ancient greek.

"And then I had to go and help him at the bakery, because he kept getting nose bleeds, he would haemorrhage and the doctor told him not to work...e...and I had some difficulty as well and my father's health problem so I had to help them, e...thirteen or fourteen I was then and I stayed (3) so that is to say straight after primary school and in high school so about then I mean thirteen fourteen I stopped that I didn't... it was difficult for me to continue. In other words those two things intervened.."

"At school ok I didn't do so well but I got as far as year 8 but I had to redo the year, and meanwhile I had a bit of an issue I wasn't very good at any of the subjects, especially maths and ancient greek (2) and that's why I failed to pass the year in high school."

She doesn't have negative experiences of work, but her re-entry into the education system is the result of her desire to get her high school leaving certificate, so as to improve her position at work and her income.

-E: How did you end up here? How did you find out about the school?

Here, I came here because I got talking about school with a colleague and from all the talk we ended up (2) and I said I wish I had finished school too because I only got as far as year 8 (2) but I said I'm scared to go back because I find it hard to meet school obligations because I believed in the learning needs of the time, the young people... and he said to me, this is what happens at this school, this happens, there, they learn like this, there is..the teachers are very understanding, in other words he knew that they adapt the lessons to the needs of the student (2) at least we who are adult learners so I said I'll go to try to see I'll go to enrol and indeed in the summer I came and enrolled..."

-E: Do you believe that the experience you gain here will help you in your work place? And in the things as you see them?

"Yes I came to move forward, for economic improvement because I'm in a sector where, in a branch where there is no promotion...I'll just change branch to earn a bit more money because I'm in a lot of debt, that's why I'm doing it. But as well as that (2) it made an impression on me and I was curious to learn what this school is and how the lessons are taught because I was stuck in the past."

\subsection{The Educators}

In their narratives the educators place the learners in two categories: those who wanted to leave education and were "forced" to return and who are not cooperative, and those who didn't want to abandon school, are aware of the gaps in their education and consequently are cooperative and can get over their negative experiences of school. We could say that a variant of the distinction "good-bad student" dominates their discourse.

As far as the ambitions of the learners are concerned, and their future plans, the educators place them in three groups based on their professional situation and age: a) those in permanent employment, usually older, public employees by profession, who need the leaving certificate for professional development or evolution, who don't have the motivation for active participation in the educational process, b) the older ones who are fulfilling a life dream, participate actively, but without further educational or professional plans and c) the younger ones, usually unemployed or in temporary employment, who participate actively, acquire skills (in computing or foreign languages) and have professional and educational dreams for the future (study at senior high school, later in higher education).

The contribution of the SCS to the learners, according to the educators, is the strengthening of their self-confidence and the provision of social skills given the marginalization they experienced due to their lack of a high school leaving certificate. To these two can be added the acquisition of knowledge and technical skills, as well as a first relationship with the educational and learning process. 


\section{Conclusions}

Through the life stories of people who abandoned school prematurely and returned after an absence of many years, we established four patterns which highlight on the one hand the importance of the economic and cultural capital of the students and on the other the role of the personal and family problems which make the situation harder and lead to the abandonment of school. The ascertainment corroborates similar studies as much in Greece (Kiprianos, 2016), (Christodoulou, 2016), (Kiprianos \& Christodoulou, 2015) as internationally (Coleman, 1996), (Bourdieu - Passeron, 1977), (National Research Council, 2001), (Janosz, 2000), (Glassman, 2000), that point to the position for the reduced impact of the education system in dropping out especially when there are no welfare mechanisms in place for the poor and for those facing personal or family problems.

The dropouts of the first pattern who went to work or got married early come mainly from low or no income families, often large with low educational capital (parents who are primary school graduates or illiterate). These parents often take the decision for their children to leave school (Bourdieu \& Passeron, 1977), especially when the latter depend on the former financially. Similar conditions are analysed in research by Archer \& Yamasita (2003), Tilleczek et al (2011) and Rumberger (2001).

Our research revealed an additional dimension, the phenomenon of the suppression and abuse of women, which not infrequently leads to school dropout. This fact was highlighted as much by the educators in their interviews as by a number of the learners who mentioned unpleasant experiential events that had scarred them. To this group belong in the main those we placed in the second pattern, the problematic situations.

The third pattern concerns individuals who lived in two countries for a long period of time and blame their dropping out of school on this "nomadic" nature of their lives. Similar results emerged from research by Kiprianos (2008) on foreigners in Greece, by Rumberger, (2001) in the USA and by Archer \& Yamasita, (2003) in Great Britain. The pattern revealed that here too children end up "paying" for their parents' decisions, as they have no say in these movements. In addition there is the language problem, either of the country of origin or the host country, which creates difficulties for learning and so for school performance too to a great extent (Bernstein, 1982).

The fourth pattern concerns those who dropped out due to learning difficulties, demonstrating that the education system as an organization and staff wasn't - and often continues not to be - in a position to support the learning of such individuals.

Finally, from the research interviews it was very apparent that school, either conventional or second chance, really helps its students, provided it makes use of the experience as a starting point for the educational process, it functions democratically in the widening, presentation and acquisition of knowledge and leads to the interaction of objective and internal experiences.

\section{$5 \quad$ Policy Implications}

The research revealed the inhomogeneity of the student population of the SCS, but went further by categorising it into four thematic fields with different characteristics, needs and expectations. We believe that the learners in each field need a different approach based on the interviews they gave us.

More specifically, the individuals in the first thematic field return to education to find or improve work, and hence they require the SCS to be linked to the job market.

The individuals in the second thematic field seek first and foremost a psychological and socialising support in addition to cognitive adequacy due to the problems they faced and/or are facing. The support of the SCS psychologist is essential for them, since it is these problems that obstruct their attendance and not inability or cognitive inadequacy. At the same time the psychologist, as well as the educators at the SCS, should be in contact with a doctor/psychologist and/or the social services which has these individuals under its protection so that mistakes in the handling of them can be avoided, but chiefly so that potential relapses or abandonment of study can be avoided.

The individuals in the third thematic field see the SCS as proof of their full linguistic, social, cultural integration into greek society. It would be good if the SCS could help these individuals in a variety of ways. Furthermore, all the foreign students want to improve their greek, but even though they require certification of their level of knowledge and even though the GREEK LANGUAGE exams 
are often held by the INEDIVIM in the space of the SCS, there is no thought to conduct language exams and provide certification for the foreign students, even though something like this is essential for them to be granted greek citizenship.

The learners in the fourth thematic field require a specialised educational approach to their learning difficulty, as well as acceptance of their problem. They need specialist certified educators or for priority to be given to the in-service training of working teachers, since in their interviews they stated their ignorance on how to deal with learning difficulties.

Proposals for the improvement of the institution of the Second Chance

1. There should be a different approach to the learners depending on their age, experience and mainly depending on the thematic field they belong to. The possibility should be allowed for the formation of class groups based on age. Perhaps also a differentiated study programme, curriculum, based on the learners' expectations.

2. In particular there should be a specialised approach for individuals with learning difficulties.

3. Advisory-psychological support which is already offered by the psychologists at the SCS to individuals in the problematic conditions category: abused women, those in trouble with the law, substance abusers, should be enhanced.

4. The educators should be offered more opportunities for in-service training.

Using age as a criterion, the learners are considered to be either young (up to 40) or old (above 40). We recommend the possible division of SCS classes based on age since the young claim to be determined to continue in formal education (Senior High School and IHE or TEI) with the aim of their professional uptake and/or development. Hence they seek more, and more demanding educational material from the teachers at the SCS, so that they can continue to senior high school on equal terms. In contrast, the older ones are studying at the SCS to fulfil a life dream, and have no desire to be put under pressure since they don't intend to continue educationally or to be recognised professionally, having already travelled life's path both personally and professionally. They seek a relaxed pace, respect from the teachers and limited educational material in class. Even the permanent public employees who are studying because they need the certification and will necessarily continue to senior high school, don't display any great zeal for the lessons, since they are interested in securing their position and their pension. The interviews revealed that the coexistence of such a range of different ages as well as social classes in the classroom creates tensions due to the differing expectations. In particular the younger teachers are "pressured" by the older learners (eg. complaint against an educator by an older learner) and back down, satisfying their demands at the expense of the younger learners (the mentality of greek society that the elders are always right and deserving of respect).

With reference to the educators, all stated their satisfaction with the fact that they work for the SCS, enjoy their important role not only as educators, but as role models for their learners and seek continuing in-service training. They even state that the SCS inspires them to train continually or to further their own education (eg. Postgraduate Studies).

\section{References}

1. Archer L and Yamashita H (2003) Knowing their limits? Identities, inequalities and inner city school leavers' post-16 aspirations, Journal of Education Policy, 18:1, pp. 53-69, DOI: 10.1080/0268093032000042209. Available at http://dx.doi.org/10.1080/0268093032000042209

2. Bernard P-Y (2011) Le décrochage scolaire. Paris : Presses Universitaires de France.

3. Bernstein B (1982) Codes, modalities and the process of cultural reproduction. In M. Apple (ed.). Cultural and Economic Reproduction in Education, London: Routledge \& Kegan Paul.

4. Bertaux D (1980) «L'approche biographique: sa validité méthodologique, ses potentialité », Cahiers Internationaux de Sociologie, 69: pp. 197-225.

5. Bonnéry St (2003). Le Décrochage scolaire de l'intérieur: Interaction de processus sociaux, cognitifs, subjectifs et langagiers. Les Sciences de l'éducation-Pour l'ère nouvelle, no. 36: pp. 39-58.

6. Bourdieu P and Passeron, J-C (1977) Reproduction in education, society and culture. London/Beverly Hills, Calif: Sage Publications.

7. Christodoulou M (2016), The biographical identities of precarious youth. How early school leavers deal with their frustrated life plans. 
8. Coleman J S (1966) Equality of educational opportunity. Washigton: U.S. Department of Health, Education and Welfare, Office of Education

9. Creswell J W. (2008), Educational Research: Planning, Conducting, and Evaluating Quantitative and Qualitative Research (3rd ed).

10.Demazière D (2003) Matériaux qualitatifs et perspectives longitudinales. La temporalité des parcours professionnels saisie par les entretiens biographiques. 10e journées sur Les données longitudinales dans l'analyse du marché du travail, Caen: LASMAS-CEREQ.

11.Demazière D and Dubar C (1997) Analyser les entretiens biographiques. L'exemple des récits d'insertion. Paris: Nathan.

12.Douat E (2012), Croire à nouveau dans l'égalité des intelligences. Les dossiers de la Ligue, pp. 6-10. Available at www.laligue.org/ ... 12/10/Decrochage-BR.pdf.

13.Dubar C (1999) L'entretien biographique comme outil de l'analyse sociologique. Revue de Sociologie et d'Anthropologie, UTIVAM

14.Fortin L (2012) Programme de prévention du décrochage scolaire au secondaire : Trait d' Union. Québec: CTREQ.

15.Glasman D (2000), Des ZEP aux REP, Toulouse: Editions Sedrap.

16.Glasman D and Oeuvrard Fr (ed.) (2011). La déscolarisation. Paris: La Dispute.

17.Hugon, M.-A. (2010). Lutter contre le décrochage scolaire : Quelques pistes pédagogiques. Informations sociales, 5: 36-45. Available at: www.cairn.info/r ... ales-2010-5-page-36.htm

18.Janosz, M. (2000). L'abandon scolaire chez les adolescents: Perspective nord-américaine. Ville-école-intégration Enjeux, 122: 105-127. Available at: www2.cndp.fr/revueVEI/122/10512711.pdf.

19.Kiprianos P (2008), Alterity, Educational Inequalities, and Educators. in E. Tzelepi-Giannatou (edit). Issues of classroom problems management. 304-316), volume II, Available at: http://www.pischools.gr/programs/sxoltaxi/tomos_B.pdf.

20.Kiprianos P and Christodoulou M (2015). Ambivalent Biographies in Adolescence: What Vocational Students Think and Feel about Their Schooling. Sage Open: 1-13. DOI: 10.1177/2158244015610795

21.Kiprianos P (2016), The Appeal of the Degree. Universities, Graduates, Trajectories, Athens: Vivliorama (in greek)

22.Lessard, A., Fortin, L. \& Joly, J. et al. (2007). Cheminement de décrocheurs et de décrocheuses. Revue des sciences de l'éducation, 33, (3): 647-662. Available at: www.erudit.org/r 007/v33/n3/018962ar.pdf.

23.Mason J (2002) Qualitative Researching London: Sage (www.sxf.uevora.pt/wp content/uploads/2013/03/Mason_2002.pdf

24.National Research Council (2001), Understanding Dropouts: Statistics, Strategies, and High-Stakes Testing. Committee on Educational Excellence and Testing Equity. Alexandra Beatty, Ulric Neisser, William T. Trent, and Jay P. Heubert, (eds). Board on Testing and Assessment, Center for Education, Division of Behavioral and Social Sciences and Education. Washington, DC: National Academy Press.

25.Patton M Q (1990). Qualitative evaluation and research methods (2nd ed.). Newbury Park, CA: Sage.

26.Riessman K C (2008), Narrative methods for the human sciences. London: Sage.

27.Rosenthal G (2004), Biographical research. In C. Seale, G. Gobo, J.F. Gubrium \& D. Silverman (eds), Qualitative research practice, London: Sage: pp. 48-64.

28.Ross A, (2013), Nice Work If You Can Get It. Life and Labor in Precarious Times, New York and London: New York University Press.

29.Rumberger, W. R. (2001). Why Students Drop Out of School and What Can be Done. For the Conference, Dropouts in America: How Severe is the Problem? What Do We Know about Intervention and Prevention? Harvard University, January 13, 2001.

30.Schütze, Fr. (1983). Biographieforschung und Narratives Interview. Neue Praxis, 13: 283-293.

31.Silverman D (2000) Analyzing talk and text. Handbook of qualitative research, 2(0), pp. 821-834.

32.Silverman, D. (2005). Doing qualitative research: A practical bankbook. London: Sage.

33.Spector-Mersel G (2010) Narrative research: Time for a paradigm. In Narrative inquiry, 20 (1): 204-224.

34.Standing G (2011), The Precariat. The new dangerous classes. New York: Bloomsbury Academic Publications. 
35.Tilleczek K, Ferguson B, Edney D R, Rummens A, Boydell K., and Mueller M. (2011) A Contemporary Study with Early School Leavers: Pathways and Social Processes of Leaving High School. Canadian Journal of Family and Youth, 3(1): 1-39.

36. Wengraf T (2000) Uncovering the General from within the Particular. From Contingencies to Typologies in the Understanding of Cases. In Pr. Chamberlayne, J. Bornat and T. Wengraf (eds), The Turn to Biographical Methods in Social Science. London: Routledge: pp. 140-164 